Winter 2016

\title{
Decentering Human Rights from the International Order of States: The Alignment and Interaction of Transnational Policy Channels
}

Radu G. Mares

radu.mares@rwi.lu.se

Follow this and additional works at: https://www.repository.law.indiana.edu/ijgls

Part of the Comparative and Foreign Law Commons, Human Rights Law Commons, International Law Commons, and the Transnational Law Commons

\section{Recommended Citation}

Mares, Radu G. (2016) "Decentering Human Rights from the International Order of States: The Alignment and Interaction of Transnational Policy Channels," Indiana Journal of Global Legal Studies: Vol. 23 : Iss. 1 , Article 8.

Available at: https://www.repository.law.indiana.edu/ijgls/vol23/iss1/8

This Article is brought to you for free and open access by the Law School Journals at Digital Repository @ Maurer Law. It has been accepted for inclusion in Indiana Journal of Global Legal Studies by an authorized editor of Digital Repository @ Maurer Law. For more information, please contact rvaughan@indiana.edu.

\section{$\Psi$}

JEROME HALL LAW LIBRARY

INDIANa UNIVERSITY

Maurer School of Law
Bloomington 


\title{
Decentering Human Rights from the International Order of States: The Alignment and Interaction of Transnational Policy Channels
}

\author{
RADU MARES ${ }^{*}$
}

\begin{abstract}
This article accounts for recent developments in corporate social responsibility, international trade and investment law, international human rights law, development aid, and the laws of home states reaching extraterritorially in order to advance a regulatory perspective on commerce and human rights. While these developments are remarkable, the analysis documents the prevalence of softer strategies and a corresponding scarcity of coercive legalization strategies. The question, then, is how to reason about these recent developments and their genuine potential for human rights protection. The article proposes two elements - a root-cause orientation and the interaction of policy channels-as indispensable for a regulatory and systemic perspective on business and human rights. To make corporate activities compliant with human rights, the emerging regulatory regime cannot afford to waste any source of leverage. In a less state-centric global order, this is a search for a multichannel, rights-holder-centered, transnational regulatory perspective that highlights alignment, interaction, and complementarity among international policy channels where strength can be achieved by creating a "rope" from weaker strands.
\end{abstract}

\section{INTRODUCTION}

In 2011, as it unanimously endorsed the Guiding Principles on Business and Human Rights, ${ }^{1}$ the U.N. Human Rights Council

* Senior Researcher, Raoul Wallenberg Institute of Human Rights and Humanitarian Law, Lund, Sweden; Associate Professor, Faculty of Law, Lund University, Sweden, radu.mares@rwi.lu.se.

Indiana Journal of Global Legal Studies Vol. 23 \#1 (Winter 2016)

(C) Indiana University Maurer School of Law 
recognized their contribution "to a socially sustainable globalization, without foreclosing any other long-term development, including further enhancement of standards." 2 That was the culmination of a six-year U.N. mandate carried out by Professor John Ruggie to bring conceptual clarity and coherence to the policy area of business and human rights. ${ }^{3}$ Ruggie maintained that progress in this area should be built on three "pillars": the obligations of states to protect human rights, the responsibilities of companies to respect human rights wherever they operate, and the access to remedies for victims of business-related infringements of human rights. The U.N. Guiding Principles are now accepted as international "soft law" and have already proved their utility by becoming the normative reference point for numerous public actors (e.g., the United Nations and states) and private ones (e.g., companies and nongovernmental organizations (NGOs)).

In regulatory terms, Ruggie broke ${ }^{4}$ with the international law ambitions of the U.N. Draft Norms ${ }^{5}$-a previous effort within the United Nations to set standards of responsible business conduct-and instead put forward a less state-centered and less law-dependent view of the emerging business and human rights regime that he called "polycentric governance." 6 The theory of change detectable behind

1. Special Representative of the Secretary-General, Guiding Principles on Business and Human Rights: Implementing the United Nations "Protect, Respect and Remedy" Framework, U.N. Doc. A/HRC/17/31, at 6-23 (Mar. 21, 2011) (by John Ruggie) [hereinafter Guiding Principles].

2. Human Rights Council Res. 17/4, Human Rights and Transnational Corporations and Other Business Enterprises, 17th Sess., May 30, 2015-June 17, 2011, U.N. GAOR, Supp. No. 53, A/17/4, श 4 (June 16, 2011).

3. See generally John GERARD RUgGIE, Just Business: MUlTinational CORPORATIONS AND HUMAN RIGHTS (2013) (discussing Ruggie's own account of the U.N. mandate).

4. See id. at 47-68 ("In my first report to the Human Rights Commission, I concluded . . . that the Norms suffered from 'exaggerated legal claims and conceptual ambiguities,' and that they were 'engulfed by [their] own doctrinal excesses.").

5. See generally United Nations, Econ. \& Soc. Council, Comm. on Hum. Rts., SubComm. on the Promotion \& Protection of Hum. Rts., Economic, Social and Cultural Rights: Norms on the Responsibilities of Transnational Corporations and Other Business Enterprises With Regard to Human Rights, U.N. Doc. E/CN.4/Sub.2/2003/12/Rev.2 (Aug. 13,2003 ) ("Reaffirming that transnational corporations and other business enterprises, their officers ... have, inter alia, human rights obligations and responsibilities and that these human rights norms will contribute to the making and development of international law as to those responsibilities and obligations.").

6. RUGGIE, supra note 3 , at xliii-xliv ("The most fundamental [aspect when developing the Guiding Principles] was to recognize and build on a core feature of the governance of multinational corporations .... Three distinct governance systems affect their conduct in relation to human rights: the system of public law . . . a civil governance system ... and corporate governance. ... [E]ach of these governance systems needs to be mobilized and pull [sic] in compatible directions."). 
Ruggie's U.N. mandate was to move to a critical mass by leveraging as many sources of authority as possible and getting them to interact in a process of cumulative progress. ${ }^{7}$ Notably, Ruggie clearly took issue with single-minded proponents of either corporate voluntarism or legalistic solutions. ${ }^{8}$ Legalization is needed, Ruggie acknowledged; however, he did not believe that starting with an international treaty would necessarily be the best way forward, especially an overarching treaty. Instead, he called for a narrow treaty-making effort and for changes to domestic law as first steps in a longer process of legalization. ${ }^{9}$ The legacy of Ruggie begins with a fundamental break in conceptualizing corporate responsibilities. He conceived of them as neither isolated from nor dependent on state obligations, embedded in a global policy context where hierarchy and formal legal authority cannot be assumed for convenience, but where public authority and the normativity of human rights seek new ways to reassert themselves, and in a human rights context where the premium is not on lofty reaffirmation of values but on leveraging all available sources of change to make a difference for rights holders.

If one would be tempted to boil down to one word Ruggie's mandate, that word would be "leverage." His quest, then, for cumulative progress would be explained as an effort to maximize that leverage through the activation and combination of all sources of leverage. ${ }^{10}$ This article

7. Id. at 78 ("[A] new regulatory dynamic was required under which public and private governance systems . . . each come to add distinct value, compensate for one another's weaknesses, and play mutually reinforcing roles-out of which a more comprehensive and effective global regime might evolve, including specific legal measures."); see also Guiding Principles, supra note 1, I 13 (discussing "cumulative progress").

8. See RUGGIE, supra note 3, at 78, 171.

9. See Mandate of the Special Representative of the Secretary-General (SRSG) on the Issue of Human Rights and Transnational Corporations and other Business Enterprises: Recommendations on Follow-Up to the Mandate, BUS. AND HUMAN RIGH'TS RES. C'TR. (Feb. 11, 2011), http://business-humanrights.org/sites/default/files/media/documents/ruggie/ ruggie-special-mandate-follow-up-11-feb-2011.pdf (recommending a follow-up mandate to embed the Guiding Principles at national and local levels and to clarify then-current international legal standards); see also John Ruggie, The Past as Prologue? A Moment of Truth for UN Business and Human Rights Treaty, INST. FOR HUM. RTS. \& BUS. (July 8, 2014), http://www.ihrb.org/commentary/past-as-prologue.html.

10. RUGGIE, supra note 3, at 124 ("[The Guiding Principles] provide a foundation for expanding the international human rights regime to encompass not only countries and individuals, but also companies. In doing so, they embrace the moral value and intrinsic power of the idea of humans rights, but also recognize that in the context of the global economy human rights can be realized in relation to business only by leveraging the multiple governance systems that shape the conduct of multinational corporations: public, civil, and corporate. Maximizing their combined leverage, however, requires a common 
reflects on this legacy from a regulatory and corporate accountability perspective, which is able to address root causes of human rights infringements and add new arrangements to enhance the protection of human rights. ${ }^{11}$ The aim is to grasp the emergence of a transnational regulatory regime that, by mobilizing new sources of public and private authority, creates a new regulatory dynamic that augments the traditional state-centered and territory-based protection of human rights with the leverage brought by international economic interdependencies and multinational enterprises (MNEs). This would move the discussion beyond the rather descriptive account of policy domains that the Guiding Principles offer in the first pillar and also reverse the tendency to silo such policy domains in academic literature. ${ }^{12}$

The questions informing this inquiry into the potential and necessity of aligning several policy domains are considered in Part I. What was the contribution of the U.N. mandate to this new regulatory dynamic? Why is it essential for a regulatory perspective to separate two main types of corporate involvement in human rights abuses? What are some noteworthy recent developments in other policy domains that bear on corporate responsibilities? Why and how can these policy domains be analyzed together with corporate responsibilities in a coherent way? Part II delves into the Guiding Principles to highlight some key notions and distinctions relevant to this inquiry as well as their significance for regulatory perspectives on business and human rights. Part III accounts for recent developments in several policy "channels" 13 in a way that highlights the mobilization, alignment, and

platform from which reinforcing effects and cumulative change can be generated." (emphasis added)).

11. The notion of "root causes" is employed in this article to point to underlying causes that might unintentionally or deliberately be overlooked when corporations and other actors respond to human rights abuses. See Radu Mares, Raoul Wallenberg Inst., Second Panel Speaker at the ESIL Third Conference, The United Nations Guiding Principles and the Root Causes of Human Rights Infringements: Is the Concept of Due Diligence up to the Task? (Sept. 3, 2014) (on file with author).

12. The literatures covering CSR, trade and labor, foreign direct investment and host country development, aid, and trade and human rights have evolved largely separately. See generally DAVID KINLEY, CIVILISING GLOBALISATION: HUMAN RightS AND THE GLOBAL ECONOMY (2009) (supplying a remarkable, though not fully integrated, treatment of policy streams).

13. This article refers to several policy domains or policy pathways as "channels" to impress the idea of alignment, interaction, and convergence on a root cause, such as weaknesses in the host state's regulatory regime. The channels examined are inter-state channels ("state-state" relations through the IHRL treaty machinery, international trade, and development assistance) and the intra-firm channel of MNEs (a company's relations 
interaction of old and new sources of leverage. Part IV situates these developments against a theoretical backdrop of the emerging transnational business and human rights regime. Besides highlighting the renewed search for policy coherence and alignment of policy channels to tackle root causes, this analysis depicts the legal institutionalization of corporate responsibilities as an attempt by public law to reassert its influence through the intrafirm channel of MNEs in a wider context of polycentric governance and multiple rationalities shaping business operations.

\section{THE CONCEPT OF CORPORATE RESPONSIBILITIES UNDER THE U.N. GUIDING PRINCIPLES}

Principle 11 of the Guiding Principles establishes the corporate responsibility to respect human rights, meaning that business enterprises "should avoid infringing on the human rights of others and should address adverse human rights impacts with which they are involved."14 Principle 13, however, is most consequential for this analysis. It defines corporate responsibility broadly, and, by differentiating levels of involvement in harm, it directs attention to separate root causes of human rights infringements in the value chain..$^{15}$ Two contexts of corporate responsibility need to be separated, as they raise decidedly different problems of legal institutionalization. This is taken up in Part I.A. Keeping the two contexts analytically separate prevents the regulatory discussion from seamlessly slipping from one context to the other, which would only seed confusion and nurture unwarranted expectations regarding available regulatory strategies. This is further explored in Part I.B. The major payoff, however, is to open a window of reflection on how exactly the policy channels described in Part III relate to each of the two contexts, and why these channels must and can overcome their weaknesses through alignment and interaction to deal with root causes of infringements.

\section{A. Contribution of U.N. Guiding Principles: Scope and Contexts of Corporate Responsibility}

Following the Guiding Principles, it is now well-accepted that a company's conduct can result in infringements of virtually all human

with its affiliates that are either managed "voluntarily" (under the label CSR) or regulated by home state laws).

14. Guiding Principles, supra note 1 , at 13.

15. Id. at 14 . 
rights, whether by operations under its direct control or those of its affiliates. In Principle 13, the Guiding Principles spell out the three scenarios-causation, contribution, linkage - to which the responsibility to respect human rights applies:

The responsibility to respect human rights requires that business enterprises:

(a) Avoid causing or contributing to adverse human rights impacts through their own activities, and address such impacts when they occur;

(b) Seek to prevent or mitigate adverse human rights impacts that are directly linked to their operations, products or services by their business relationships, even if they have not contributed to those impacts. ${ }^{16}$

Principle 13, read in conjunction with Principle 19, defines the scope of corporate responsibility broadly and is a significant legacy of the U.N. mandate. ${ }^{17}$ Harms occurring in the operations of subsidiaries, subcontractors, and other business partners are clearly covered through the responsibility to respect human rights. The company has a responsibility to identify and address such impacts on human rights not only in its own operations, as in the workplace or local community, but also in affiliates' operations abroad. Breaking conceptually with the past, Ruggie argued that what determines the existence of the responsibility to respect is "impact" (meaning a human right is infringed somewhere in the value chain), not "leverage" (meaning the ability of a company to influence the entity in the value chain). In this way, Ruggie explicitly rejected the traditional corporate approach towards supplychain management; the latter would often stop at the first tier of suppliers over which the buyer had contractual leverage, while ignoring severe abuses happening at lower tiers of the value chain. As a consequence of this conceptualization, the company has a responsibility for harms occurring in third-party operations even if it did not contribute in any way to the human rights violation (linkages scenario), or if its conduct reflects only a partial and/or remote causality to the

16. $I d$.

17. See Int'l Trade Union Conference, The Untted Nations "Protect, Respect, REMEDY" FramewORK FOR BUSINESS AND HUMAN RIGHTS AND THE UNITED NaTIONS GUIDING PRINCIPLES For Business and Human RIGHTS: A GUIDE for Trade UnIONISTS, 17-18 (2012), available at http://www.ituc-csi.org/TMG/pdf/12-04-23_ruggie_background_ fd.pdf. 
harm (contribution scenario). From this broad scope of the responsibility to act, two major aspects are visible through root cause lenses and in terms of responsibility (to act) to exercise leverage.

In a transnational context, Principle 13 puts forward two types of root causes: one lying squarely with the core company (Type 1 cause), ${ }^{18}$ and another root cause having to do with the affiliate and its regulatory environment; that is, the host country's legal regime under which the affiliate in the value chain operates (Type 2 cause). Staying in the multinational-enterprise context, the "triad" causation-contributionlinkages contained in Principle 13 reveals distinct root-cause contexts: "causation" refers to Type 1 cause, "contribution" to both Type 1 and 2 causes, and "linkages" to Type 2 cause. The implications are profound. First, the core company cannot obscure a root cause under its control merely because the harm occurred remotely in an affiliate's operations and causality is indirect, given third-party involvement. ${ }^{19}$ Such a culpable core company cannot hide behind the remoteness of impacts, and maybe the failings of its affiliate, but has to acknowledge Type 1 causes and the harm generated by its own decisions. Second, the core company cannot separate itself too easily from another root cause (Type 2 cause regarding the affiliate's conduct and the host country regulatory regime) just because the company did not cause the harm through its own culpable decisions. The company is still linked to adverse impacts through its business relationships and has to first exercise leverage to address the negative impacts before cutting links with the supplier. ${ }^{20}$ In other words, the company cannot disclaim Type 2 causes and pursue

18. The term 'core company' refers herein to influential companies operating through subsidiaries and global supply chains. See Virginia Harper Ho, Theories of Corporate Groups: Corporate Identity Reconceived, 42 SETON HALL. L. REV. 879, 886-91 (2012) (detailing the characteristics of corporate groups, parent companies, and subsidiary entities).

19. Examples of this kind may involve the decisions of buyers to change styles often or on short notice, or more broadly to devise sourcing arrangements that rely on flexibility, fast turnaround and low costs, which create downward pressures on suppliers; a foreseeable consequence is suppliers not complying with labor standards. See RICHARD M. Locke, The Promise and Limits of Private Power: Promoting Labor Standards in a GLOBAL ECONOMY 126-29 (2013) (detailing relationship between upstream business practices and factory-level labor conditions); see also infra pp. 26-27.

20. Guiding Principles, supra note 1, at 19 ("If the business enterprise has leverage to prevent or mitigate the adverse impact, it should exercise it. And if it lacks leverage there may be ways for the enterprise to increase it. Leverage may be increased by, for example, offering capacity-building or other incentives to the related entity, or collaborating with other actors. There are situations in which the enterprise lacks the leverage to prevent or mitigate adverse impacts and is unable to increase its leverage. Here, the enterprise should consider ending the relationship, taking into account credible assessments of potential adverse human rights impacts of doing so."). 
business as usual by resorting to legal technicalities, such as not owning or contracting with the supplier whose operations infringe human rights, or pointing to practical difficulties of having limited leverage, if any. The impact still has to be addressed, and there are multiple modalities to exercise leverage over Type 2 causes.

In terms of a responsibility to act, the Guiding Principles do not impose impossible or unreasonable requirements on the core company for impacts occurring throughout the value chain. ${ }^{21}$ The major difference for current purposes is that depending on the root cause, the responsibility to respect becomes a responsibility to cease harmful conduct in the context of Type 1 causes (the "causation" and "contribution" scenarios) and a responsibility to exercise leverage over the third party in the context of Type 2 causes (the "linkages" and "contribution" scenarios) before termination of relationship is contemplated. Clearly the responsibility to exercise leverage is more complicated from a regulatory angle, both in its justification (why should the company act?) as well as, and especially, in terms of specifying and enforcing the company's duty to act (how to exercise leverage?). Therefore, Part I.B distinguishes the "cessation" regime from the "leverage" regime, corresponding to Type 1 and Type 2 root causes, respectively.

It is, however, not enough to note that the responsibility to respect-in Principle 13-has a broad scope encompassing the two root causes; it is important that the operational concept of human rights due diligence-Principles 17-21-does not fracture the message and also displays a decisive root-cause orientation in identifying and addressing impacts. A root-cause orientation is essential for due diligence to go beyond treating symptoms and superficial causes and instead uncover deeper causes wherever they might be in the value chain and thus enable appropriate action by the company, alone or in conjunction with other policy channels. ${ }^{22}$ One can detect in the Guiding Principles and explanatory materials a proper root-cause orientation. The Interpretive

21. For example, the responsibility of core companies merely "linked," under Principle 13(b), to abusive third parties does not include remedying the harm; the responsibility to remediate remains with the affiliate and the host state per Principle 22. See Guiding Principles, supra note 1, at 14, 20-21.

22. When it comes to root causes of infringements of human rights in the affiliate's operations, a diversity of root causes are identifiable including: those in and outside of the value chain; those in corporate decisions taken in host or home states; and those in the domain of the law (repressive or inadequate regulations), market (profit-maximization and cost-cutting tendencies throughout the value chain), or societal conditions (poverty, cultural attitudes and management style, and so on). One cause of non-compliance with human rights standards is always the disincentive coming from host government's law and practice (either repressive laws or non-enforcement of adequate laws). 
Guide issued by the U.N. Office of the High Commissioner for Human Rights (OHCHR), to which Ruggie contributed, explicitly mentions "root cause analysis" as one method useful in tracking effectiveness, which is the due-diligence step outlined in Principle 20.23 Later works from organizations with which Ruggie is associated explicitly interpret the due-diligence concept in terms of root causes. ${ }^{24}$

\section{B. Legal Institutionalization of Corporate Responsibility}

With a root-cause orientation established, it is important to discern the harder and softer regulatory and nonregulatory options available to policymakers to tackle each of the two types of root cause. The two regimes corresponding to each type are kept analytically separate in order to assess the opportunity of harder or softer strategies to alter business conduct and the role of the policy channels in tackling root causes under each regime.

As to strategies of legal institutionalization, there are major differences between the two regimes. Under the "cessation regime" (cause-contribute), dealing with Type 1 cause (i.e., the core company's own misconduct), "hard" legal institutionalization of the corporate responsibility to respect in the form of coercion and instituting a prohibition of harmful conduct is not conceptually difficult. Indeed, the "cessation regime" can be approached through classical principles of civil and criminal liability. By contrast, "softer" legal institutionalization always appears inadequate to the task of ensuring the company is ceasing its harmful conduct. In fact, there are both legal precedents and legal principles to rely on to cover such torts and crimes, even though they occur, in our discussion, in a transnational setting. ${ }^{25}$ Indeed, notwithstanding that infringements of human rights occur in the operations of the affiliate, the type of root cause addressed by this regime is the same-Type 1 . Because the core company appears as an accomplice or joint tortfeasor, difficulties for legal institutionalization of the responsibility to respect arise only in establishing legal elements of liability such as causality, proximity, foreseeability, fault, and so on. Here it is essential to strive to keep the two regimes analytically separate and not slip seamlessly from "cessation" to "leverage," a

23. See U.N. Office of the High Comm'r for Hum. Rts., The Corporate Responsibility to Respect Human Rights: An Interpretive Guide 54, HR/PUB/12/02 (2012) ("A root cause analysis can help pinpoint what actions by which parts of the enterprise, or by which other parties related to the enterprise, played a role in generating the impact, and how.").

24. Mares, supra note 11.

25. Legal suits from UK and Canada are at hand. See, e.g., Choc v. Hudbay Minerals, Inc., 2013 ONSC 1414 (Can.); Chandler v. Cape [2012] EWCA (Civ) 525 (U.K.). 
slippage often encountered in insufficiently specified arguments over an "MNE's social responsibility" that misrepresent the corporate involvement in abuse and stretch legal argumentation to a breaking point. Where a limit is reached, rather than risking inconsistency with principles of tort and criminal liability, the discussion could be carried further in terms of linkage to harm and accompanying responsibility to exercise leverage. That, however, raises different challenges for hard and soft legal institutionalization.

The "leverage regime" (contribute-linkages) tackles Type 2 root causes; that is, the affiliate's misconduct and the inadequacies of the host country's regulatory regime. In contrast to the "cessation regime," under the "leverage regime" the company respects human rights infringed by its affiliate's operations by exercising its leverage, not merely by ceasing its own conduct. Indeed, the matter is not one of cessation. Rather, according to Principle 19, only when leverage fails is the company asked to cease, to sever the relationship with the abusive affiliate. Under the "leverage regime," the task of legal institutionalization is not one of prohibition, but of mobilizing and guiding leverage. Could hard, coercive legal strategies hitting at the top of the value chain (core company) -as in the "cessation regime"achieve this leverage objective? As a matter of precedent, hard legal institutionalization options are scarce in this context. Recent transnational regulatory regimes prohibiting the trade in "tainted goods," such as illegal timber or conflict minerals, might appear to furnish analogues, but the analogy does not hold. Hard regulatory strategies lead to incentives for premature disengagement by core companies, thus harming rights holders rather than protecting them. ${ }^{26}$ This makes such coercive strategies problematic in the human rights context. Here, the importance of mobilizing and preserving the leverage produced in the intrafirm channel is paramount, as witnessed by NGO advocacy that rarely calls for disengagement from problematic affiliates. The enemy is hasty disengagement as opposed to "last resort" disengagement. The Guiding Principles reflect this concern by sequencing the appropriate action expected under the "linkages" scenario as leverage first, terminate relationship second. ${ }^{27}$ Therefore, any hard institutionalization options targeting solely the core companies have to be assessed against the real danger of actually destroying the leverage added by the intrafirm channel rather than securing that

26. See Child Labor Deterrence Act (Harkin Bill) of 1993, S. 613, 103d Cong. (exemplifying the unintended effects on right-holders (child laborers) of a hard law strategy that, if enacted, would have banned the importing of goods produced with child work).

27. See Guiding Principles, supra note 1, at 18-19 (Principle 19 Commentary). 
leverage. Softer legal institutionalization strategies-such as transparency regulations--suddenly become more attractive. The question, then, is how to ensure that softer strategies actually make a difference, which is where the multichannel perspective comes into play as the key to legally institutionalizing the "leverage" regime.

As to the role of public policy channels, they can clearly support the "cessation regime" and thus legalize the corporate responsibility to respect. State channels-international human rights law, trade, investment, home state laws-employ legal instruments that could "host" the responsibility of core companies and thus address Type 1 root causes. References to the social responsibilities of MNEs in such instruments would create hard or soft legal incentives for core companies to act responsibly. When it comes to the "leverage" regime, the state channels- international human rights law, trade, investment, aid-are relevant not simply as potential "hosts" for the social responsibilities of companies, but equally as channels impacting directly on the host state. A host state, as party to such international agreements and cooperation schemes, could be expected to meet some human rights standards within their territories by regulating domestic companies which appear as affiliates in multinational groups and networks. Thus these state channels target directly the host state's regulatory regime, and so Type 2 root causes. The opportunity then arises for the often limited leverage that core companies have over their suppliers to align naturally with, and potentially interact with, the leverage summoned by other policy channels targeting the root causes of inadequate host state regulations and affiliate misconduct. Part II gives examples of the aforementioned possibilities in several policy channels for mobilizing and aligning leverages in order to tackle root causes.

\section{NeW Developments in Five Policy Channels}

This section highlights promising developments in five policy channels: international trade law, international human rights law, development aid, home state laws with extraterritorial effects, and "corporate social responsibility" (CSR). There are some seeds for optimism, precedents, and experiments coming to maturity in these areas. What is notable is that human rights appear as a legitimate concern in old and new policy channels: traditional channels promoting human rights (such as human rights and development aid) have been joined by economic channels that previously shunned human rights concerns (such as trade and the intrafirm channels of MNEs). What is more, as witnessed by myriads of cross-references and joint programs presented in this section, these channels increasingly interact and align, 
creating opportunities to harvest and direct their combined leverage towards the root causes of human rights infringements. The openness, interdependency, and ubiquity of economic exchange make it slightly harder for public and private decision makers to avoid scrutiny and responsibility for their decisions' impacts on human rights. The challenge is to capitalize on this opening and devise a regulatory perspective on business and human rights encompassing "state-state channels" and "intrafirm channels," and knitting harder and softer institutionalization strategies into a protective network for rights holders. In examining these new regulatory dynamics, I focus on how these channels address root causes and on the actual or potential alignment and interaction of these channels.

\section{A. State-State Channels: International Trade Law}

This section analyses the relation between labor rights and international trade law by discussing the progression from the Word Trade Organization (WTO) stalemate of the mid-1990s; to the multitude of (mainly bilateral) free trade agreements including labor clauses; to the emergence of more complex trade agreements that include, inter alia, investment provisions (an amalgamation of trade and investment aspects); and finally to the ongoing negotiations of megaregional agreements between industrialized countries (e.g., the U.S.-EU Transatlantic Trade and Investment Partnership currently being negotiated).

When the WTO was established in 1994 , it was the culmination of decades of effort to liberalize international trade. At the time, the WTO arrangement was questioned for not dealing with social aspects linked to the production of goods and services traded internationally. ${ }^{28}$ The controversy centered on whether a "social clause" should be included within the WTO agreements to protect labor and human rights. ${ }^{29}$ The matter was settled in the 1996 Singapore Ministerial Declaration, which passed the task of protecting labor rights to the International Labour Organization (ILO). ${ }^{30}$ As a result, the linkage between trade and labor rights was cut at the multilateral level. ${ }^{31}$ The multilateral WTO trade law, however, allows states the possibility to agree to further

28. See KINLEY, supra note 12 , at $47-50$.

29. See id.

30. See World Trade Organization, Singapore Ministerial Declaration of 13 December 1996, WTO Doc. WT/MIN(96)/DEC, at ๆ 4, available at https://www.wto.org/english/ thewto_e/minist_e/min96_e/wtodec_e.htm.

31. Regarding the limited opportunities for raising human rights issues under article XX of WTO, see KINLEY, supra note 12, at 66-67, 70-77. 
liberalization measures on a bilateral or regional basis (resulting in Free Trade Agreements), as well as giving preferential trade terms to less developed states willing to pursue their development objectives through facilitated access to the markets of developed countries (resulting in General System of Preferences). The link between trade and labor and human rights flourished at these two levels of Free Trade Agreements (FTAs) and General System of Preferences (GSPs).

The proliferation of FTAs-bilateral or regional-is a notable development not only for their growing number, but also for the inclusion of labor clauses in fifty-eight out of 250 trade agreements, ${ }^{32}$ something that appeared unthinkable years ago during the WTO controversy. The social clauses vary in content, with approaches ranging from asking the state to not lower or fail to implement existing domestic labor law protections, to adopting laws that uphold the ILO's fundamental labor rights. ${ }^{33}$ In terms of implementation, the majority of FTAs (60 percent) contain promotional strategies only, and where more coercive options exist they have been rarely activated. ${ }^{34}$ That indicates that the bulk of implementation efforts are bound to be of a cooperative rather than coercive nature, or a softer rather than hard institutionalization strategy. It is an indication that the state-state trade channel has managed to overcome the suspicions of protectionism arising from attempts to include a social clause backed by hard, coercive sanctions at the multilateral level of the WTO by proceeding instead at bilateral and regional levels with a social clause backed largely by softer, cooperative measures..$^{35}$ It is a testament to the state-state trade channel surprisingly managing to deliver leverage towards Type 2 root causes; in the same time it is a limited leverage that highlights the necessity to seek alignment with other policy channels. The state-state channel thus provides some leverage to address Type 2 root causes, but it is limited, and must be supplemented by other means.

What do these FTAs reveal in terms of the potential for interaction with other channels? Clearly, the cooperation provisions point towards an easy alignment with the development-aid and human-rights-law channels, as both aim to strengthen the capacity of host-state

32. As of 2013 , there were 58 trade agreements (out of 248) including social clauses (those concluded by the United States, European Union, and Canada). INT'L INST. FOR Labour Stud., Social Dimensions of Free Trade Agreements 5, 19 (rev. ed. 2015) [hereinafter IILS].

33. See generally Fraser Simpson, Labour Rights Protections within International Trade: A Study of Free Trade Agreements and Generalised Systems of Preferences (2015), available at http://papers.ssrn.com/sol3/papers.cfm?abstract_id=2686050.

34. See IILS, supra note 32 , at 69 . This point has been illustrated in four cases involving the United States. Id. at 3.

35. See generally KINLEY, supra note 12 , at 66-68. 
institutions to devise and implement adequate labor laws. What of interaction with the intrafirm channel? The connection is not a natural one, as pure trade agreements address the macro-level of trade at which states reduce tariffs on goods crossing their borders. The intrafirm channel, by contrast, addresses the micro-level of trade through corporate value chains where responsible business practices would cover top-down efforts by core companies and industries (CSR) as well as bottom-up efforts by suppliers to gain private certification (i.e., fair trade regimes). One frequently cited example is the U.S.-Cambodia Textile Agreement. In this agreement (terminated in 2004 due to the expiration of the Multi Fibre Arrangement), the United States promised to increase quotas for Cambodian exports should the Cambodian government commit to labor standards in its garment industry. The result was the Better Factories Cambodia (BFC) scheme, ${ }^{36}$ a special compliance program for the garment industry that did not pursue compliance with labor standards in a classic manner through public regulation and labor inspections, but generated an alternative arrangement in the form of a private scheme. The BFC attracted the involvement of the ILO and the International Finance Corporation (IFC) (the human-rights-law and development-aid channels) as well as that of international buyers (the CSR channel) that relied on the credible audits performed by BFC. The BFC can be seen as an example of alignment and convergence of different channels to address a Type 2 root cause and deliver a locally protective arrangement for Cambodian workers. Triggered by the trade agreement (the trade channel, through a hard legal strategy of conditioning market access), several other channels (the aid, human-rights-law, and intrafirm channels through CSR) aligned and converged on a formalized private protective scheme.

The European Union has put forward its "values-based trade agenda," containing modern FTAs and GSPs. Notably, the 2012 EU Communication on Trade, Growth and Development expressly refers to "private sustainability-bound schemes (e.g. fair, ethical or organic)" and CSR. ${ }^{37}$ It is a reference to the intrafirm channel that points the reader towards the interaction of channels. Furthermore, in its policy paper, the Communication demonstrates a positive disposition to intervene at different key points of the intrafirm channel (value chain), from one end in developed countries by stimulating demand though public procurement, to the other end in developing countries by supporting

36. See BETTER FACTORIES CAMBODIA, http://betterfactories.org (last visited July 9, 2015).

37. Commission Communication on Trade, Growth and Development and Tailoring Trade and Investment Policy for Those Countries Most in Need, at 14, COM (2012) 22 final (Jan. 27, 2012). 
responsible exporters and local certification schemes. ${ }^{38}$ The search for coherence is clearly detectable and CSR (intrafirm channel) is explicitly on the agenda, ${ }^{39}$ but more needs to be done to move beyond what currently appears as mere enumerations of policy domains and toward a more clearly conceptualized interaction and complementarity of channels. ${ }^{40}$ This can also improve the historically weak implementation record and thus exert more leverage on Type 2 root causes. ${ }^{41}$

This article impressed so far that in dealing with developing countries, there is a shift underway in trade law from the potentially coercive and unilateral GSP approach since 1970,42 and from the pure trade law approach of tariff-reducing trade agreements from the 1990s, toward more encompassing FTAs that include labor clauses and predominantly employ cooperative, capacity-building measures. ${ }^{43}$ This important shift needs to be placed in an even broader context. FTAs grow in complexity too by including at times investment protections that otherwise would have been found in pure investment instruments like bilateral investment treaties (BITs). With such economic agreements that amalgamate trade and investment aspects comes the possibility to refer directly to "CSR," 44 which is imported into the trade agreement through the investment-related provisions. It is a reference to the intrafirm channel that can potentially commit both home and host states to strengthening the legal obligations of MNEs and affiliates. Thus the trade and investment agreement can become a "host" for the corporate responsibility to respect in a very different way than the U.S.-Cambodia trade agreement, which created an opportunity

38. See id. at 9-15.

39. An in-depth study of EU policies found that "the inter-linkages between trade, investment, development cooperation and human rights are actively being operationalised by the EU's institutions. ... [This indicates] a sense of a 'fresh start [sic] for the EU to take the lead in implementing a more consistent, coherent and effective external action which prioritises human rights." Laura Beke, et al., Report on the Integration of Human Rights in EU Development and Trade Policies, at 141-42, Deliverable No. 9.1 (2014).

40. See Expert Conference on Guiding Principles, Copenhagen, May 7-8, 2012, From Principles to Practice: The European Union Operationalizing the United Nations Guiding Principles on Business and Human Rights, 3, 10 (2012) (highlighting issues of policy coherence, leverage, and alignment of policies).

41. For a recent in-depth study of European FTAs and GSPs, see Beke et al., supra note 39 , at $140-41$.

42. See Cecilia Malmström, Comm'x for Trade, Eur. Comm'n, EU Africa Trade: A New Partnership (June 3, 2015).

43. See Simpson, supra note 33 , at 20-43 (describing several free trade agreement examples containing labor clauses).

44. The European Union states that "[m]odern and pro-development trade policies" address a complex range of issues, from trade facilitation to social and environmental regulations, investment, intellectual property rights, competition, and government procurement. Commission Communication, supra note 37 , at 5 . 
rather than a responsibility for international buyers, and an obligation on the host state of Cambodia. Having an investment instrument (as opposed to a trade instrument) refer to CSR and the intrafirm channel is nothing new in itself. Indeed, the OECD Guidelines on Multinational Enterprises, one of the first and most authoritative international soft law instruments on CSR, has since 1976 accompanied the rules on investment that the OECD states have been promoting. ${ }^{45}$ The only problem was that such references to the responsibilities of investors (or CSR), as laid down in the OECD Guidelines, remained voluntary and thus amounted to a soft strategy of linking investment to human rights. Even worse, investment agreements (the nearly $3000 \mathrm{BITs}$ ) offered broad, legally enforceable protection for their commercial interests. ${ }^{46}$ Indeed, from a human rights perspective, the debate has always been about the imbalance in investment agreements between the legal rights of investors and their absent hard legal obligations; and between the ability of investors to enforce their rights through international arbitration and the corresponding shrinking policy space of host states to pursue social and environmental public aims (e.g., the right to regulate and stabilization clauses). .47

This amalgamation of trade and investment provisions in modern FTAs, therefore, can give rise to charges of hypocrisy against developed states: on one hand, the trade provisions affirm the social clause and build capacity of host states (thus addressing Type 2 root causes), and on the other hand, the investment provisions exacerbate Type 2 root causes (undermining the "right to regulate" of host states) and ignore Type 1 root causes (investors' rights are not accompanied by human rights obligations) while at most paying lip service to investor responsibilities through lofty CSR pronouncements. It is therefore important to place such a potentially devastating blow to the modern trade channel in its wider context: that of the very recent megaregional agreements. ${ }^{48}$ Their arrival is set to address the concerns of civil society over the excesses of the BITs ${ }^{49}$ by safeguarding the host state's right to

45. Org. for Econ. Cooperation \& Dev. [OECD], Declaration on International Investment and Multinational Enterprises, 15 I.L.M. 967 (June 21, 1976).

46. Trade for All: Towards a More Responsible Trade and Investment Policy, at 21 (October 2015), available at http://trade.ec.europa.eu/doclib/docs/2015/october/tradoc_ 153846.pdf.

47. See RUGGIE, supra note 3 , at $182-7$.

48. For the multiple causes beyond these mega-regional agreements, see Steve Woolcock, The Impact of Mega Regional Agreements on International Investment Rules and Norms, 13 SWEDISH INST. FOR EUR. POL'Y STUD. 4 (2015).

49. See Karl P. Sauvant, The Times They Are A-Changin'-Again-In the Relationships between Governments and Multinational Enterprises: From Control, to Liberalization to Rebalancing, COLUMBIA FDI PERSPECTIVES, No. 69, May 21, 2012, at 2-3. 
regulate and by adjusting the international arbitration mechanism previously so favorable to investors. ${ }^{50}$ Furthermore, whether the responsibilities of investors for their human rights impacts will be "hosted" by such agreements-in a legally binding form or not-remains an open question. ${ }^{51}$ These changes are the result of international investment law evolving beyond the developed states-developing states negotiations to a new paradigm involving developed states-developed states negotiations, where old rules are being questioned and likely improved. These corrections are a good sign for investment law itself, as they remove glaring pro-investor excesses and insert CSR references, as well as for trade law, which has grown in complexity to include "labor clauses" but risks being undercut by outdated investment provisions.

In sum, the modern trade law approach and the potential of the international trade channel appear promising from a root-cause perspective and interaction-of-channels standpoint, with the caveat that an implementation approach that prefers cooperation to coercion can deliver softer rather than harder leverage to the business and human rights regime.

\section{B. State-State Channels: International Human Rights Law (IHRL) and Development Aid (ODA)}

The policy domains of IHRL and ODA have traditionally had a direct bearing on inadequate regulatory regimes in host countries but are also finding new ways to relate to the intrafirm channel, trade, and investment. Thus, on one hand, the IHRL channel-through its treaty bodies $^{52}$ and special procedures ${ }^{53}$-is discharging, more effectively and at a level of higher quality, its limited powers to ensure host states

50. See Euro. Parl. Comm. on Int'l Trade, Rep. Containing the European Parliament's Recommendations to the European Commission on the Negotiations for the Transatlantic Trade and Investment Partnership, at 17-18, Doc. A8-0175 (June 1, 2015).

51. See id. at 17 (asking TTIP negotiators to "[e]nsure that TTIP contains a comprehensive chapter on investment .. . [and addresses] investors' obligations and responsibilities by referring, inter alia, to the $O E C D$ principles for multinationals enterprises and to the UN principles on Business and human rights benchmarks.").

52. See generally U.N. Commissioner for Human Rights, Strengthening the United Nations Human Rights Treaty Body System, U.N. Doc. AV66/860 (June 2012) (by Navanethem Pillay); G.A. Res. 68/268, U.N. Doc. A/RES/68/268 (Apr. 21, 2014).

53. See generally INGRId NIFOSI, THE UN SPECIAL PROCEDURES IN THE FIELd OF HUMAN RIGHTS (2005); Surya P. Subedi et al., The Role of the Special Rapporteurs of the United Nations Human Rights Council in the Development and Promotion of International Human Rights Norms, 15 INT'L J. HUM. RTS. 155 (2011). 
comply with their international obligations.54 A multichannel perspective on business and human rights does not obscure or downplay such progress, but seeks ways to reinforce it and enhance the leverage of IHRL standards and mechanisms. On the other hand, additional to this traditional focus on host states, there is currently an evolution in U.N. oversight mechanisms and academic scholarship toward discussing the responsibility of home states, usually under the "extraterritorial obligations" label.55 For example, international trade and investment agreements that home states negotiate with developing countries should be subject to human rights impact assessments, as proposed by the Special Rapporteur on the Right to Food. ${ }^{56}$ Furthermore, U.N. treaty bodies and special procedures give more attention to the intrafirm channel. Thus, the issuance of the Guiding Principles in 2011 markedly empowered U.N. human rights bodies to comment on the home states' failures to influence their companies operating abroad and to ensure such companies employ human rights due diligence. ${ }^{57}$ This trend is set to continue with the Committee on Economic, Social and Cultural Rights explicitly stating it will continue to request information from home states about MNEs falling within their jurisdictions. ${ }^{58}$ In addition, several U.N. Special Rapporteurs—on water and sanitation, the right to

54. See U.N. Secretary-General, Compilation of Guidelines on the Form and Content of Reports to be Submitted by States Parties to the International Human Rights Treaties: Rep. of the Secretary-General, If 11, U.N. Doc. HRI/GEN/2/Rev.6 (Jun. 3, 2009).

55. See, e.g., Hum. Rts. Comm., Concluding Observations on the Sixth Periodic Rep. of Ger., Oct. 15-Nov. 2, ๆ 16, U.N. Doc. CCPR/C/DEU/CO/6 (Nov. 12, 2012) ("The State party is encouraged . . . to take appropriate measures to strengthen the remedies provided to protect people who have been victims of activities of such business enterprises operating abroad.").

56. See Special Rapporteur on the Right to Food, Guiding Principles on Human Rights Impact Assessments of Trade and Investment Agreements: Report of the Special Rapporteur, 19th Sess., If 1.1, at 5, U.N. Doc. A/HRC/19/59/Add.5 (Dec. 19, 2011) (by Olivier De Schutter).

57. See U.N. Secretary-General, Contribution of the United Nations System as a Whole to the Advancement of the Business and Human Rights Agenda and the Dissemination and Implementation of the Guiding Principles on Business and Human Rights, ๆף 19, 35-36, U.N. Doc. A/HRC/21/21 (July 2, 2012) ("Treaty bodies may use the Guiding Principles . . to inform their dialogue with States parties under the treaty reporting process, individual complaints and in the elaboration of general comments, statements and other treaty body output that address States parties' obligations.").

58. See Comm. on Econ., Soc., \& Cultural Rts., Statement on the Obligations of States Parties Regarding the Corporate Sector and Econ., Soc., and Cultural Rights, May 2-20, 2011, ๆ| 6-7, U.N. Doc. E/C.12/2011/1 (May 20, 2011) ("[T]he Committee calls on States Parties to include in their initial and periodic reports information on challenges faced and measures taken in relation to the role and impact of the corporate sector on the realization of economic, social and cultural rights."). 
food, indigenous peoples, and the freedom of expression-released thematic reports on business impacts on specific human rights. ${ }^{59}$

It is apparent that U.N. treaty bodies and special procedures have developed a sharper focus on trade and investment at the interstate and intrafirm levels; they seek to maximize the soft legal institutionalization capacity of the IHRL channel by expanding their focus beyond host states' compliance to cover the obligations of home states and the responsibilities of commercial entities. Interpreting treaty law and relying on soft law instruments such as the Guiding Principles, U.N. bodies are developing more finely tuned assessments and concrete recommendations for the interstate and intrafirm economic channels. In return, economic channels like the EU General System of Preferences or the CSR-type Better Factories Cambodia scheme rely on the compliance assessments of ILO and its technical expertise in labor issues. ${ }^{60}$ These point to a growing interaction between the IHRL channel and economic channels in an effort to tackle root causes of infringements of human rights throughout the value chain.

Development cooperation has for a long time referred to rule of law, democracy, human rights, and good governance. ${ }^{61}$ In this way, the human rights performance of host states (Type 2 root causes) has been traditionally addressed through the aid channel by developed states either offering economic aid backed by (negative or positive) human rights-related conditionalities ${ }^{62}$ or directly supporting processes and institutions relevant to human rights. ${ }^{63}$ In terms of implementation, the aid channel featured the full spectrum of mechanisms, from capacitybuilding to soft persuasion and even coercion, to enhance the human rights regime in recipient countries. ${ }^{64}$ Furthermore, as the

59. See generally GLobal BuS. Initiative on HuM. RTS. \& INST. For HuM. RTS. \& BuS., STATE of PlaY: THE CORPORATE RESPONSIBILITY TO RESPECT HUMAN RIGHTS IN BUSINESS RELATIONSHIPS 58 (2012) [hereinafter STATE OF PLAY].

60. For example, the EU GSP mechanism assesses state compliance with human and labor rights by relying on the findings of the ILO and UN monitoring bodies. See Commission Regulation 978/2012, arts. 9.1(b), 13, 14.3, Annex VIII, 2012 O.J. (L 303) 7, 8, 60-61 (EU).

61. See generally KINLEY, supra note 12 , at 93-104 (detailing the historical developments and main interaction between economic aid, development, and human rights).

62. See Beke et al., supra note 39, at 91-92 ("Conditionality can affect three levels of decision making: deciding on the choice of partner countries (also referred to as 'selectivity'), the amount of ODA to be provided to a country, and the way in which this assistance is provided.").

63. See id. at 121-30 (discussing integration of human rights considerations in programming processes).

64. See id. at 71 (discussing the examples of the little effective GSP+ sanctions taken against Belarus and Myanmar). 
developmental paradigm shifted away from state-driven development models, ODA has concentrated increasingly on private sector development and on linking local businesses to international markets. This led not only to public-private partnerships for development, but also led naturally to ODA support for CSR. Thus ODA has supported the intrafirm channel directly by building capacity around responsible value chain management for more than a decade now. Notably, support has gone to different strategic points of the intrafirm channel: support directly for affiliates to gain access to international markets, to corporate accountability NGOs, to multistakeholder CSR initiatives, and to standardization efforts in view of the essential role of standards in global trade. Channeling funds to promote responsible business conduct has also been politically convenient for home states reluctant to adopt stronger regulatory approaches to their multinationals. Finally, the ongoing alignment of ODA with the modern trade law agenda has proceeded as the latter expanded to emphasize more institutional strengthening in relation to labor rights, environmental protections, rule of law, and regional integration. In sum, ODA, with its softer strategies of capacity building and sometimes accompanied by stronger strategies involving human rights conditionalities, relates easily to root causes-whether host states or companies throughout the intrafirm channel-and adds its leverage to other policy channels addressed here.

\section{Intrafirm Channel: Home-State Regulations and Corporate Voluntarism}

Corporations respond to hard and soft legal institutionalization of corporate responsibilities, but also to organizational, market, and societal stimuli. Developments in the intrafirm channel have been notable. A range of regulations in home states has recently appeared, most prominent being transparency laws that cover social and environmental impacts of corporate activities, both at home and abroad. The highest profile example of disclosure regulation of a broad applicability is the 2014 EU Directive, with national laws to enter into force in 2017.65 Other significant and recently adopted laws relate to specific issues such as transparency of payments in the natural resource sector and conflict minerals. ${ }^{66}$ This is a notable step forward from the pioneering though extremely general legal requirements that were

65. Council Directive 2014/95/EU, art. 4, 2014 O.J. (L 330) 8.

66. See, e.g., Dodd-Frank Wall Street Reform and Consumer Protection Act, Pub. L. No. 111-203, $\S 1502,1504,124$ Stat. 1376, 2213-18, 2220-22 (2010). 
placed on financial companies ${ }^{67}$ or on large companies ${ }^{68}$ in few jurisdictions around the year 2000. "Transparency" has been a constant rallying call of corporate accountability groups eager to move beyond self-regulation and corporate voluntarism schemes. Although a legal requirement, the route between such transparency laws and respecting human rights is tortuous; coercion is indirect and uncertain as it will come from market and societal actors, not from courts or regulatory agencies. This is a soft legal institutionalization approach, particularly so when information disclosed covers broad areas in a rather general manner, less so when it is highly specific. ${ }^{69}$ Such laws start a dialogue, prompt corporate learning through self-assessments inherent in preparing a public report, and, should that fail, may facilitate societal mobilization to influence companies.

Another significant action-whether to be characterized as a soft or hard legalization strategy-by home states is of a contractual nature, given that states are not only regulators but economic actors too: states are buyers in the area of public procurement, ${ }^{70}$ and financial actors in investments, credits, and guarantees for companies operating abroad. ${ }^{71}$ As with transparency laws, states are in the position to apply leverage at the top of the value chain by asking core companies to demonstrate that they undertook human rights due diligence. There is also the angle of transnational litigation, by definition a hard law strategy targeting the intrafirm channel at the very top with coercive civil or criminal legal action. While the territorial boundaries are not an obstacle per se, ${ }^{72}$ this strategy targets only Type 1 root causes, as the principles of tort law

67. See, e.g., Occupational Pension Schemes (Investment, and Assignment, Forfeiture, Bankruptcy etc.) Amendment Regulations, 1999, c.2 § 4(b) (U.K.).

68. See, e.g., Loi 2001.420 du 15 mai 2001 relative aux nouvelles régulations économiques [Law 2001-420 of May 15, 2001 on New Economic Regulations], LEGIFRANCE, Feb. 20, 2002.

69. See Elizabeth R. Gorman, When the Poor Have Nothing Left to Eat: The United States' Obligation to Regulate American Investment in the African Land Grab, 75 OHIO ST. L.J. 199, 226-28 (2014) (discussing the application of Dodd-Frank).

70. See Council Directive 2014/24, art. 18, 2014 O.J. (L 94) 105-06 (EU). See generally Olga Martin-Ortega et al., Buying Power and Human Rights in the Supply Chain: Legal Options for Socially Responsible Public Procurement of Electronic Goods, 19 INT'L J. HUM. RTS., 341 (2015) (detailing the potential of the EU legal regime for public procurement as a tool for the promotion of human rights in the electronics industry supply chain).

71. See Guiding Principles, supra note 1, at $\S \S 4-6$.

72. Note the "presumption against extraterritoriality" established by the U.S. Supreme Court in Kiobel v. Royal Dutch Petroleum Co., 133 S.Ct. 1659, 1663-69 (2013). See generally Roger Alford, Kiobel Insta-Symposium: The Death of the ATS and the Rise of Transnational Tort Litigation, OPINIO JURIS (April 17, 2013), http://opiniojuris.org/2013/ 04/17/kiobel-instthe-death-of-the-ats-and-the-rise-of-transnational-tort-litigation (discussing the future of the Alien Tort Statute after Kiobel). 
applied in such cases require a strong involvement of the core company (own culpable conduct) in the affiliate's abusive operations. ${ }^{73}$

Moving beyond home state regulation of MNEs, leading companies have adopted progressive CSR strategies that increasingly reveal a rootcause orientation in "diagnosing" human rights infringements in affiliate operations and "curing" those infringements through alignment-of-channels strategies. It is important to note the evolution in CSR strategies based on twenty years of sometimes unsuccessful efforts that created a better understanding in the business sector itself of the limits of simplistic depictions of CSR, whereby influential core companies can and should compel weaker entities in the value chain to "clean up their act." Facilitated by shortcomings-and-failures of (dyadic) CSR where the company "polices" its contractors into compliance, the field of CSR has evolved to a stage where leading companies demonstrate awareness of, and take action on, root causes consisting of their own decisions (Type 1) as well as root causes pertaining to the affiliate and the host state's regulatory environment (Type 2). This clearly requires a notion of CSR that is aware of, and interacting with, other policy channels, which are increasingly open to alignment and interaction to maximize leverage over root causes.

Regarding Type 1 causes, there are now frank admissions from some companies about how their own practices contribute to infringements throughout the supply chains. Nike, for example, made stunning acknowledgements about its own contributions to labor abuses abroad. Excessive overtime, for example, was found to be caused by Nike's own decisions in 68 percent of cases. ${ }^{74}$ Nike is also restructuring its supply chain to pursue longer-term relationships with key suppliers. ${ }^{75}$ This frankness makes it disingenuous to frame an affiliate's noncompliance as being rooted exclusively in causes present locally in the host state, and makes it more difficult for MNEs to shift the blame wholesale to the affiliate (a supplier's social irresponsibility) or to the host state (government inability or unwillingness to regulate suppliers), thus obscuring downward pressures on affiliates created by MNEs and cutthroat market competition (the "invisible hand" of hypercompetitive markets). This root cause of value-chain problems is now not only

73. See Choc, 2013 ONSC 1414, supra note 25, at II 44-53.

74. Nike wrote that it "continued to assess root causes of excessive overtime . . . [It was able to establish that $68 \%$ of incidents analyzed] were attributable to factors within Nike's control, primarily forecasting or capacity planning issues, shortened production timelines and seasonal spikes." NIKE INC., NIKE, INC. FY10/11 SUSTAINABLE BUSINESS PERFORMANCE Summary, 20, 53 (2012).

75. See STATE OF PLAY, supra note 59, at 109 (discussing the growing trend and opportunities involved with supply chain consolidation). 
identified as such by "antiglobalization" NGOs, but is also supported by corporate documents and highlighted by the Guiding Principles in Principle 13 (the "contribution" scenario).

As a result, easy justifications for inaction or for simplistic "policing the direct suppliers" approaches are fading. A new focus on root causes delivers a better understood responsibility to assess one's own contributions (Type 1) and also to exercise leverage over others (Type 2). The approach of H\&M and other brands to the issue of "living wage" in Cambodia defines expressly the role of buyers vis-à-vis the role of the host government and unions in creating a mature industrial relations system by involving the ILO and drawing on Swedish development aid. Such a strategy addresses Type 2 root causes, as it puts government, employers, and labor on notice that it is not the buyers' role to set wages. ${ }^{76}$ However, these buyers have not overlooked Type 1 root causes, as these brands are committed to keep sourcing as long as local parties are committed to a proper settling of the wage issue. ${ }^{77}$ This commitment is essential, as it tackles the possibility of buyers redirecting purchasing orders-a facile compliance strategy for buyers to separate themselves from human rights abuses-and thus enables local actors to improve their conduct by removing a significant disincentive for suppliers and the host government, fearful of diminishing the international competitiveness of their industry.

As to Type 2 root causes, the last decades of CSR reveal that, often, the effective.solution to affiliate noncompliance is not to be found in the dyadic buyer-supplier relationship, with its mistaken corollary of the buyer having to only monitor and audit the affiliate. ${ }^{78}$ This is a simplified, often inappropriate or insufficient, way of exercising leverage in the value chain. To tackle local root causes, more complex strategies should be pursued. For example, the Rana Plaza factory collapse in Bangladesh that killed over 1,100 workers resulted in two industry responses: the Accord and the Alliance. ${ }^{79}$ Furthermore, the European

76. Press Release, H\&M, Response to Business \& Human Rights Resource Center, http://www.business-humanrights.org/sites/default/files/documents/H\&M-response-22-92014.pdf (last visited July 9, 2015).

77. Letter from Philip Chamberlain, C\&A Head of External Stakeholder Engagement, et al., to H.E. Keat Chhon, Permanent Deputy Prime Minister of the Royal Government of the Kingdom of Cambodia (Sept. 18, 2014) (on the upcoming wage negotiations), http://about.hm.com/content/dam/hm/about/documents/masterlanguage/CSR/Others/Lette r\%20to\%20DPM\%20Cambodian\%20Government\%20September\%202014.pdf.

78. This approach largely unchanged over the last 20 years. See STATE OF PLAY, supra note 59 , at 66 .

79. See generally Accord on Fire and Building Safety in Bangladesh, May 13, 2013, available at http:/www.achact.be/upload/files/Bangladesh_Accord_on_fire_and_building_ safety_2013.pdf; Member Agreement of the Alliance for Bangladesh Worker Safety, July 
Union, ILO, and the government of Bangladesh reacted with a "Sustainability Compact" in 2013 aimed at raising labor standards in the export-oriented textile sector. ${ }^{80}$ Here, the ILO provides expertise and technical assistance to the government as it strengthens labor laws, while the European Union resorts to its development aid programs to fund such improvements. Among the key deliverables of this joint effort, freedom of association takes center stage through the introduction of the ILO-IFC Better Work Programme in Bangladesh to improve industrial relations and dialogue at the enterprise level. Other measures refer to a larger number of labor inspectors and a publicly accessible database as a platform for reporting labor, fire, and building safety inspections. Exemplifying alignment of policy channels, the Sustainability Compact welcomes the Accord as an example of buyers coordinating their efforts. In sum, the advanced CSR strategies of leading companies today evince a root-cause orientation and a search for more complex solutions, revealing alignment and interaction with other policy channels.

\section{A Multichannel, Transnational Regulatory Perspective on BUSINESS AND HUMAN RIGHTS}

The operations of MNEs and the increasing integration of national economies through international trade and investment agreements expose the territorial state, and the international human rights law order relying on states, to new challenges. For human rights, these challenges take the shape of new threats as international economic law instruments augment the influence of transnational economic forces and markets, which are not inherently sensitive to distributional aspects like human rights risks and impacts. There are also new opportunities for human rights to bypass well known structural weaknesses of international human rights law where enforcement options are generally weak and dependent on states' commitments. ${ }^{81}$ Both these

2013, available at http:/www.bangladeshworkersafety.org/files/Alliance-Member-AgreementFINAL.pdf.

80. Sustainability Compact for Continuous Improvements in Labour Rights and Factory Safety in the Ready-made Garment and Knitwear Industry in Bangladesh, Bangl.-ILO-EU, July 8, 2013, available at http://trade.ec.europa.eu/doclib/docs/ 2013/july/tradoc_151601.pdf.

81. See John Ruggie, Progress in Corporate Accountability, InST. FoR HuM. RTS. \& Bus. (Feb. 4, 2013), http:/www.ihrb.org/commentary/progress-in-corporate-accountability.html ("Expanding the international human rights regime to encompass business conduct runs smack into some the most prominent features of the current world polity and global economy: national sovereignty; competition among states for markets, investments and access to resources; the emergence of new global powers with their own views about both business and human rights; weak or corrupt governments in many countries; competition 
threats and opportunities present legal theory with pressing challenges as how best to secure the normativity of international human rights across boundaries-territorial, organizational, and policy-domain boundaries-in new ways that both are feasible and maximize leverage in the service of human rights. Conceptual treatments of human rights in a less state-centered global order do not seek mistakenly to reinforce distinctions such as those between hard and soft law, between legal and nonlegal, private and public, territorial and extraterritorial, but to transcend such distinctions with a decisive focus on root causes and a search for new regulatory arrangements to tackle them. ${ }^{82}$ In this sense, decentering the legal protection of human rights represents as much a challenge to a state-hegemonic concept of international human rights law under threat from globalized economic interdependencies as it is an opportunity for law to reassert itself through old and new policy channels and regulatory strategies to secure human rights. 83

The role of states in ensuring responsible business conduct has been clarified in recent years. First, the classic international human rights law stance remains as relevant as ever, with territorial states expected to respect and ensure human rights within their jurisdiction. Second, the role of states-whether home states of MNEs or host states-in institutionalizing human rights due diligence is also clear, given precedents in numerous other legal fields. ${ }^{84}$ Third, the references to "smart policy mixes" dispel previously misguided framings of CSR as "voluntarism" only, ${ }^{85}$ and orient attention to the major task of aligning policy channels. Here is my area of focus. I highlighted three sets of

among firms for profits and market share; the corporate law principles of the legal separation between parent company and affiliates, coupled with investors' limited liability; asymmetries of capacity and influence between large companies and many governments; large swaths of conflict zones; few and highly contested bases of extraterritorial jurisdiction - the list goes on.").

82. See, for example, how the IHRL channel is capturing this orientation in the ILO 2014 Protocol to the Forced Labour Convention. Article 2 states that the measures to address forced labor include "(e) supporting due diligence by both the public and private sectors to prevent and respond to risks of forced or compulsory labour; and (f) addressing the root causes and factors that heighten the risks of forced or compulsory labour." Protocol of 2014 to the Forced Labour Convention (P029), 1930, art. II, June 11, 2014 (emphasis added), available at http://www.ilo.org/dyn/normlex/en/f?p=NORMLEXPUB: 12100:0::NO::P12100_ILO_CODE:P029.

83. Kinley deemed this opportunity as "one whose vital importance cannot be overlooked." KINLEY, supra note 12, at 169.

84. See Olivier De Schutter et al. Human Rights Due Diligence: The Role of STATES 49-55 (2012).

85. See Communication from the Commission to the European Parliament, the Council, The European Economic and Social Committee and the Committee of the Regions, at 3, 67, COM (2011) 681 final (Dec. 25, 2011) (detailing the a new definition that includes the multidimensionality of CSR). 
opportunities on which the emerging regulatory regime of business and human rights is being built: first, the opening up of state economic channels to human rights aspects, especially modern trade law; second, the human rights-dedicated channels (human rights law and, partly, development aid), which are not content with pursuing the territorial state's compliance with ratified treaties, which they strive to do in a more effective way, but are paying increased attention to economic channels (trade) and the intrafirm channel (MNEs); and third, the opportunities to enhance leverage through alignment, complementarity, and interaction of policy channels (policy coherence and "smart" policy mixes).

The relevance of states and public law is not diminishing in human rights, as I have argued, but there are new sources of leverage to be captured and new pathways toward human rights protection that emerging regulatory regimes mobilize and institutionalize. ${ }^{86} \mathrm{I}$ argue that a root-cause perspective and the softer legal institutionalization performed in several policy channels are two factors that should not be overlooked; indeed, they are indispensable to bringing together the policy domains in a common conceptual treatment, as well as to pursuing a strategy of change that seeks gaining strength by aligning weak policy channels normatively and making them interact institutionally. In other words, it is a picture of a regulatory regime coming to terms with the multiple, though limited, tools in its arsenal and therefore seeking to gather strength by bundling together weak strands (soft legal institutionalization options) into a "rope" that targets root causes of problems rather than their symptoms. This strategy is indispensable with respect to Type 2 root causes, and promises to send to the host governments a consistent message on multiple channelseconomic as well as classical channels dedicated to human rights-that the local regulatory regime should ensure respect for human rights while other participants in international trade come to perceive credible, locally embedded arrangements (from local laws to private certification of affiliates) as an inherent component of their mandates and social responsibilities.

86. Eberlein and colleagues write about Transnational Business Governance (TBG) as being "rooted in a regulatory governance perspective that views TBG as a dynamic, coregulatory, and co-evolutionary process involving state, non-state, and hybrid actors and organizations that pursue varied interests, possess different regulatory capacities, and interact at multiple levels and in multiple ways, with a range of effects." BURKARD EBERLEIN ET AL, TRANSNATIONAL BUSINESS GOVERNANCE INTERACTIONS: CONCEPTUALIZATION AND FRAMEWORK FOR ANALYSIS 16 (2013), available at http://ssrn.com/abstract=2347166. 
To return to the U.N. Guiding Principles, my argument here is compatible with the "polycentric governance" of the Guiding Principles, with the "smart mix" of laws and policies that regulators increasingly invoke, and with the multistakeholder collaborations known from the CSR movement of the last twenty years. Many believe that the U.N. mandate marked a qualitative leap in reasoning about business and human rights. In human rights due diligence, Ruggie saw a conceptual device for breaking through organizational boundaries which, in law, are embodied by the principle of separation of entities. ${ }^{87}$ Ruggie bet on the risk-management dimension of due diligence to prompt core companies to action to address impacts wherever they might happen in the value chain. ${ }^{88}$ Powered by a due diligence concept able to cross organizational boundaries within multinational value chains, the responsibility to respect became capable of crossing territorial boundaries as well. Indeed, Ruggie stressed that extraterritoriality of state obligations is a controversial concept that proponents and opponents unnecessarily use wholesale. Instead, Ruggie maintained, home states regulating their own companies is not the same as home states directly regulating affiliates domiciled abroad, which would indeed be extraterritorial and problematic. ${ }^{89}$ In this way, the corporate responsibility to respect human rights, and particularly human rights due diligence, not only captured a business rationality that is not dependent on law and state action, ${ }^{90}$ but also became potential vehicles for future legal institutionalization efforts in various policy domains. Ruggie's work created the possibility for law to reassert itself globally through the intrafirm channel, ${ }^{91}$ allowing endless combinations of public regulation, private regulation, standardization and capacity-building measures involving a multitude of policy channels.

87. See RUGGIE, supra note 3 , at $188-189$ (" $[\mathrm{H}]$ ow do we get a multinational corporation to assume the responsibility to respect human rights for the entire corporate group, not atomize it down to its various constituent units? . . . Under the corporateresponsibility-to-respect-human-rights pillar, I did not set out to establish a global enterprise legal liability model. . . . My aim was to prescribe practical ways of integrating human rights concerns within enterprise risk-management systems.").

88. Radu Mares, "Respect" Human Rights: Concept and Convergence in LAW, BUSINESS And Human RIghts: BRIdGing The GAP 3, 22-35 (Robert C. Bird et al. eds., 2014) (demonstrating how Ruggie's strategic bet in due diligence navigated around the separation of entities principle).

89. RUGGIE, supra note 3, at 140-41.

90. The Guiding Principles state that the corporate responsibility to respect "exists independently of States' abilities and/or willingness to fulfil their own human rights obligations." See Guiding Principles, supra note 1, at 13.

91. Ruggie believes that "some form of further international legalization in business and human rights is both necessary and desirable" but the issue for the SRSG mandate "has never been about international legalization as such." Ruggie, supra note 9. 


\section{CONCLUSION}

Where human rights protections and rule of law are weak, human rights are predictably and regularly being infringed upon by business operations. The analysis started with the Guiding Principles, which put forward a corporate responsibility to respect human rights and exercise human rights due diligence. The responsibilities of multinational enterprises were clarified and then placed in a wider context. Instead of a uni-channel treatment of business and human rights focused on the intrafirm channel of MNEs and the parent company's responsibilities, the analysis advanced a multichannel perspective on the affiliate companies because their operations directly impact rights holders. Such affiliates respond to stimuli from their international value chain and their domestic regulatory environment.

My aim was to identify relevant policy channels and to assess their force in bringing affiliate companies into compliance. The relevancy was determined according to the direct and indirect impact of each policy channel on the business affiliate. Thus, the intrafirm channel was immediately relevant, as were any policy channels impacting the host state, which has an indisputable obligation to safeguard human rights under classical international human rights law. Channels-old and new-focused on human rights, commerce, or development were covered: CSR, international human rights law, trade law, development aid, and home state regulations. The analysis highlighted notable openings and documented increased interactions among policy channels. The force for change exerted by these policy channels was assessed in terms of harder or softer institutionalization strategies directed towards the business affiliate, the core company, and the host state. The decision was to not discard policy channels that carry softer forms of leverage, as the emerging transnational regime cannot afford to waste any source of leverage.

The question, then, is how to reason about softer institutionalization strategies. If they should not be discarded, and if they are not necessarily evolving to deliver coercive forces, how can their impact be meaningful in an area like human rights where the stakes are so high? The article dealt with this question in two ways: by separating two contexts of corporate responsibility and by proposing an integrated assessment of policy channels. First, the analysis in Part I clarified two contexts that can be discerned from the widely endorsed Guiding Principles. In one such context, coercion is clearly warranted, precedents in tort law exist, and coercive legal solutions could be adopted at international and home state levels. This separation of the two contexts prevents sliding seamlessly from one context to the other 
through inattentive or deliberately misleading argumentation. This cleared the way for the analysis of softer institutionalization strategies.

Second, to account for softer institutionalization strategies the article focused on the interactions of policy channels and their dispositions to acknowledge and tackle root causes. Thus two key elements-a root-cause orientation and the interaction of channelsare proposed as indispensable for a regulatory and systemic perspective on business and human rights. Part II presented encouraging recent developments in five policy channels that display a proper orientation and interaction. The thesis here is that the emerging transnational regulatory regime can increase leverage through the alignment of policy channels and the bundling of softer legal and nonlegal institutionalization strategies into a stronger "rope." This has legal and human rights significance.

In sum, the article put forward a multichannel, rights-holdercentered, transnational regulatory perspective that descriptively accounts for new developments in key policy areas, analytically examines the points of interactions and complementarity among relevant policy channels linked to international commerce, and normatively seeks the alignment of these channels to deal with root causes of human rights abuses in business operations. 